\title{
STRATEGI PEMBIAYAAN PENDIDIKAN PADA MADRASAH SWASTA UNGGULAN
}

\section{EDUCATION FINANCING STRATEGY IN FAVORITE PRIVATE MADRASAHS}

\author{
Muhamad Murtadlo \\ Puslitbang Pendidikan Agama dan keagamaan \\ Jl. MH Thamrin No. 6 Jakarta Pusat \\ Email : tadho25@gmail.com
}

Naskah diterima 1 Februari 2016, direvisi 20 Februari 2016, disetujui 30 Maret 2016

\begin{abstract}
Education financing is often considered to be a major problem to encourage private madrasahs to be favorite schools. This study is intended to examine the strategy of financing education carried out by one of the favorite madrasahs. The study is based on a case study of a favorite madrasah around the capital city Jakarta. This study found the education funding model that can deliver this madrasah to earn the predicate of "madrasah unggul" from the Ministry of Religious Affairs. Based on the experience of this madrasah, parent participation in education funding must be offset by the provision of quality assurance to education service customers.
\end{abstract}

Keywords: Strategy, Education Financing, Favorite Madrasahs

\begin{abstract}
Abstrak
Pembiayaan pendidikan sering dianggap menjadi masalah utama untuk mendorong madrasah swasta menjadi sekolah unggulan. Penelitian ini ingin mengkaji strategi pembiayaan pendidikan yang dilakukan oleh salah satu madrasah unggulan. Kajian didasarkan pada studi kasus terhadap madrasah unggulan di sekitar ibukota Jakarta. Kajian ini menemukan model pembiayaan pendidikan yang mampu mengantarkan madrasah ini memperoleh predikat madrasah unggul dari Kementerian Agama RI. Berdasarkan pengalaman madrasah ini, partisipasi orang tua dalam pembiayaan pendidikan harus diimbangi dengan memberikan jaminan kualitas terhadap konsumen pendidikan.
\end{abstract}

Kata Kunci: Strategi, Pembiayaan Pendidikan, Madrasah Unggulan 


\section{PENDAHULUAN}

Kebijakan negara yang mengalokasikan $20 \%$ APBN untuk pendidikan tidak serta merta menjadikan madrasah swasta lebih baik. Bahkan sebaliknya dalam beberapa hal, kebijakan pendidikan gratis justru menyulitkan madrasah swasta untuk berkembang. Bantuan Operasional Siswa (BOS) yang menjadi dasar kebijakan pendidikan gratis ternyata pada prateknya lebih banyak mencover operasional pendidikan yang bertujuan langsung kepada kebutuhan siswa, sementara masalah fundamental madrasah swasta, yaitu insentif guru berupa gaji dan honor guru madrasah swasta tidak difikirkan.

Belum lagi kebijakan desentralisasi pendidikandenganmenyerahkanpembinaan sekolah ke pemerintah daerah telah menyebabkan polarisasi atau pengkutuban antara sekolah dengan madrasah. Dampak yang paling kelihatan adalah adanya perbedaan tingkat kesejahteraan antara guru sekolah dengan guru madrasah. Kebijakan ini masih mengesankan menciptkan suasana diskrimatif perlakuan pemerintah daerah terhadap sekolah dengan madrasah. Guru-guru sekolah mendapatkan kesejahteraan tambahan dari pemerintah daerah, sedangkan guru madrasah tidak mendapatkan bantuan kesejahteraan. Di satu sisi, UU Sisdiknas No. 20/2003 menyiratkan semua kegiatan penyelenggaraan pendidikan dituntut melakukan desentralisasi, tetapi di sisi lain UU Pemerintahan Daerah No. 22/1999 menyuratkan bahwa bidang agama tidak termasuk bidang yang didesentralisasikan (instansi vertikal). ${ }^{1} \mathrm{Hal}$ ini berakibat bahwa pemerintah daerah tidak mau memberi bantuan pembiayaan dalam bentuk apapun kepada instansi yang dianggap vertical seperti madrasah di Kementerian Agama.

Interpretasi pemerintah daerah seperti itu sebenarnya belum bisa diterima oleh kalangan praktisi madrasah. Walaupun mereka juga tidak bisa berbuat apa-apa atas perlakuan diskriminasi pemerintah daerah ini. Para praktisi madrasah merasa bahwa mereka sama-sama menyelenggarakan pendidikan formal, mendidik putra-putri bangsa, dan menyelenggarakan ujian nasional yang sama dengan sekolah umum. Karena itu perlakuan yang membedakan madrasah dengan sekolah umum dirasa tidak adil (diskriminatif) oleh para praktisi madrasah, apalagi di madrasah mayoritas justru lembaga swasta.

Sumbangan masyarakat madrasah dalam mensukseskan Program wajib belajar sebanrnya tidak kecil. Wajib belajar di Indonesia yang dimulai dengan wajib belajar sekolah dasar 6 tahun (Wajar 6 Tahun), dan itu telah dilaksanakan sejak tahun 1984. (Tilaar, 2000). Dari peningkatan APK, Sumbangan masyarakat madrasah yang dikoordinasikan Kementerian agama (kemenag) untuk tiga tahun (2005-2007) dapat dilihat sebagai berikut: pada jenjang MI/SD, APK pada tahun 2005 sebesar 13,20 $\%$, tahun 2006 sebesar 13,70\%, dan tahun 2007 sebesar 14,20 \%. Sedangkan untuk tingkat MTS menunjukkan angka partisipasi

1 UU No. 22 tahun 1999 Pasal 7 ayat (1) berisi:"Kewenangan Daerah mencakup kewenangan dalam seluruh bidang pemerintahan, kecuali kewenangan dalam bidang politik luar negeri, pertahanan keamanan, peradilan, moneter dan fiskal, agama...." 
pada tahun 2005 sebesar 17,40\% tahun 2006 sebesar 18,50\%, dan tahun 2007 sebesar $19,60 \%$.

Di samping kenaikan APK, sumbangan madrasah adalah menekan angka dropout yang bisa digambarkan: untuk jenjang MI/ SD tahun 2006 sebesar 0,6\% menjadi 0,4\% pada tahun 2007 untuk MI dan untuk MTs, sebesar 1,06 \% tahun 2006 menjadi 1,02\% pada 2007. Pada tahun 2008 angka drop out MI dan MTs turun menjadi 1,04 \% sedangkan APK pada MI dan MTs masing-masing mencapai $14,75 \%$ dan $20,70 \%{ }^{2}$

Kemenag mencatat bahwa jumlah lembaga pendidikan madrasah tidak kurang dari $18 \%$ dari seluruh lembaga pendidikan di Indonesia. Sedangkan besaran prosentasi tanggung jawab kementerian agama dalam penuntasan wajar Dikdas secara nasional, dihitung berdasarkan proporsi siswa yang belajar di madrasah dan salafiyah dibagi jumlah peserta didik yang tertampung di sekolah, madrasah, salafiyah, paket, sekolah terbuka dikalikan 100\%. Maka proporsi tanggung jawab kemenag secara nasional untuk MI adalah 9,77\% dan untuk MTs $20,38 \%{ }^{3}$

Sumber pendanaan pendidikan di madrasah sejauh ini beragam, bukan hanya dari pemerintah melainkan dari keluarga siswa dan masyarakat. Dasar perhitungan biaya pendidikan selama ini lebih didasarkan pada sumber-sumber anggaran pemerintah (rutin dan pembangunan), dengan agak mengabaikan kontribusi dan peran serta keluarga. Padahal hanya dengan kontribusi

${ }^{2}$ Paparan Dirjend. Pendis pada dengar Pendapat Komisi VIII DPR RI, Januari, 2008.

3 Buku Penuntasan Wajar Dikdas Sembilan Tahun 2004-2009, Direktorat Pendidikan Madrasah) dari keluarga dan sumber-sumber nonpemerintah tersebut, proses pendidikan dapat berlangsung meskipun dana pemerintah berkurang. Misalnya, ketika dana DAU (Dana Alokasi Umum) belum cair dan madrasah harus menyelenggarakan Ujian, madrasah memperoleh dana itu dari sumber-sumber non-pemerintah termasuk dari keluarga siswa.

Setelah adanya kebijakan nasional pemberian Bantuan Operasional Siswa (BOS) bagi semua siswa-siswa usia wajib belajar pendidikan dasar (Wajardikdas) di Indonesia, maka madrasah tidak diizinkan lagi menarik biaya pendidikan dari siswa. kebijakan pendidikan gratis ini pada prakteknya justru menyulitkan madrasah swasta untuk berkembang. Akibat dari kebijakan ini, mau tidak mau ada beberapa inisiatif satuan pendidikan dalam mensikapi dana BOS dan konsekwensinya Ada madrasah yang menerima BOS dan tidak lagi memungut SPP dari siswa, ada madrasah yang menerima BOS dan memungut biaya tambahan, bahkan ada yang ekstrim menolak BOS. ${ }^{4}$

Berdasarkan konteks masalah seperti itu, kajian ini ingin mengungkap bagaimana repon madrasah terhadap kebijakan pendidikan gratis yang dikembangkan oleh pemerintah saat ini? Dan bagaimana sebaiknya madrasah swasta mengelola biaya pendidikan? Untuk menjawab pertanyaaan itu, maka penelitian ini mencoba menelaah beberapa penelitian yang telah penulis lakukan sebelumnya, dan secara khusus dihubungkan dengan kasus Madrasah Pembangunan Ciputat Tangerang. Madrasah Pembangunan dipilih karena madrasah

${ }^{4}$ Contoh madrasah yang menolak BOS adalah Madrasah Matholih di Kajen Pati. 
swasta ini berhasil mengatasi problema pembiayaan, bahkan madrasah itu dianggap unggul di sekitar Ibukota DKI Jakarta. Madrasah yang dimaksud adalah Madrasah Ibtidaiyah Pembangunan Ciputat Tangerang Selatan.

Kajian ini bertujuan untuk menggambarkan strategi dan jalan keluar bagi madrasah swasta di tengah kebijakan pendidikan gratis yang dikembangkan pemerintah. Strategi ini diakui tidak bisa diterapkan semua madrasah swasta, karena pembiayaan satuan madrasah swasta sangat ditentukan oleh situasi dan kondisi yang melingkupinya. Bagi madrasah swasta yang mengagagas keunggulan, maka tulisan ini bisa menjadi inspirasi. Hal ini penting mengingat prosentase madrasah swasta di Indonesia besar sekali, yaitu mencapai $92 \%$.

Ada beberapa dasar penghitungan satuan biaya (unit cost) pendidikan dalam berbagai kepustakaan yang ada. Beberapa dasar penghitungan satuan biaya itu antara lain: penghitungan berdasarkan biaya langsung (direct cost) dan biaya tidak langsung (indirect cost); penghitungan berdasarkan biaya pribadi (privat cost) dan biaya social (social cost); atau penghitungan berdasarkan biaya dalam bentuk uang (monetary cost) dan bukan uang (nonmonetary cost). ${ }^{5}$ Di samping itu ada juga model penghitungan Biaya tetap (fixed cost) dan Biaya tidak tetap ( variable cost ); Biaya investasi dan biaya operasional; Biaya total ( Total cost) dan Biaya satuan (Unit cost). Dari beberapa teori di atas, penelitian ini memilih

${ }^{5}$ Dedi Supriadi. 2003. Satuan Biaya Pendidikan: Dasar dan Menegah, Bandung: PT Remaja Rosdakarya, h. 4 pendekatan analisas biaya total (total cost) dan biaya satuan (unit cost).

Untuk mengkaji pembiayaan pada satuan pendidikan madrasah sebagai salah satu lembaga pendidikan yang dikelola kementerian agama, maka tidak ada salahnya kita menengok beberapa penelitian yang mencoba menghitung kebutuhan pendidikan pada berbagai jenis kelembagaan. Sejumlah penelitian yang mengkaji tentang pembiayaan pendidikan di likungan kementerian agama bisa disebutkan antara lain penelitian Rochmat Mulyana dkk. (2005), Puslitbang Penda (2006), Abdul Muin dkk. (2007), Murtadlo dkk (2011).

Rochmat Mulyana dkk. dalam kajiannya Unit Cost Mahasiswa IAIN/STAIN mencoba memetakan kebutuhan pembiayaan untuk masing-masing mahasiswa selama menempuh pendidikan di lingkungan STAIN, IAIN dan UIN. Penelitian ini menyebutkan beberapa metode penghitungan unit cost mahasiswa seperti: penghitungan yang didasarkan pada jumlah subsidi yang diberikan pemerintah melalui DIK dan DIP; penghitungan berdasarkan estimasi pengeluaran mahasiswa; dan penghitungan berdasarkan kebutuhan seluruh komponen pendidikan di PT. Dari ketiga metode ini, penelitian ini memilih metode ketiga, yaitu menghitung unit cost berdasarkan peta kebutuhan seluruh komponen pendidikan di PT. ${ }^{6}$

Penelitian Puslitbang Penda tentang "Studi Unit Cost Satuan Pendidikan di Madrasah Swasta" yang dilakukan

6 Rochmat Mulyana dkk. 2005. Unit Cost Mahasiswa IAIN/STAIN, Jakarta: Puslitbang Pendidikan Agama dan Keagamaan. 
Puslitbang pendidikan agama dan keagamaan kementerian Agama RI bekerja Sama dengan Peneliti Universitas Pendidikan Indonesia (UPI) Bandung pernah menghasilkan Komponen-komponen yang seharusnya dibiayai dalam penyelenggaraan satuan pendidikan pada jenjang pendidikan madrasah swasta tingkat MI dan MTs agar memiliki kualitas dan daya saing dengan jenis-jenis pendidikan persekolahan lainnya. Daftar kebutuhan tersebut terdiri dari tujuh komponen utama dan 57 rincian. Ketujuh komponen itu terdiri dari: 1) Komponen Kesejahteraan Personel; 2) Komponen Pengembangan Personel; 3) Komponen Penunjang KBM; 4) Komponen Pemeliharaan dan Penggantian; 5) Komponen Daya dan Jasa; 6) Komponen Pembinaan Kesiswaan; 7) Komponen Rumah Tangga Madrasah (Overhead) ${ }^{7}$

Penelitian lain, Abdul Muin dkk. dalam Biaya Satuan Madrasah Diniyah Awaliyah. Penelitian ini mencoba menghitung kebutuhan pembiayaan dalam penyelenggaraan madrasah diniyah awaliyah. Pendekatan metode yang digunakan adalah menggunakan penghitungan berdasarkan komponenkomponen kebutuhan pembiayaan madrasah diniyah awaliyah yang dirumuskan sebelumnya oleh tim peneliti. Selanjutnya untuk kelengkapan data, penelitian ini membuka kesempatan kepada satuan madrasah diniyah awaliyah (MDA) untuk menyebutkan kebutuhan pembiayaan lain yang mungkin diperlukan ${ }^{8}$.

${ }^{7}$ Penelitian Puslitbang Penda. 2006. Studi Unit Cost Satuan Pendidikan di Madrasah Swasta. Jakarta: Puslitbang Pendidikan Agama dan Keagamaan

${ }^{8}$ Abdul Muin dkk. 2007. Biaya Satuan Madrasah Diniyah Awaliyah. Jakarta: Puslitbang Pendidikan
Penelitian Murtadlo dkk dalam Studi Pembiayaan Pendidikan di Madrasah menyebutkan bahwa Apabila wacana pendidikan gratis diimplementasikan di madrasah, maka Kementerian Agama RI harus menyiapkan dana tambahan untuk pembiayaan kebutuhan dasar pembelajaran di madrasah, mengingat dana BOS yang tersalurkan selama ini, baru mengkover sebagian dari kebutuhan tersebut dan belum mengalokasi insentif guru dan tenaga pendidikan secara layak. ${ }^{9}$

\section{METODOLOGI PENELITIAN}

Untuk menjawab pertanyaaan itu, maka penelitian dilakukan dengan metode penelitian kualitatif, dengan pendekatan studi kasus. Kasus yang diambil adalah pembiayaan pendidikan di madrasah swasta, yaitu Madrasah Pembangunan Ciputat Tangerang.Madrasah Pembangunan dipilih karena madrasah swasta ini berhasil mengatasi problema pembiayaan, bahkan madrasah itu dianggap unggul di sekitar Ibukota DKI Jakarta. Untuk memperkaya data, peneliti menggunakan perbandingan data dengan beberapa penelitian tentang pembiayaan pendidikan yang lain.

\section{HASIL DAN PEMBAHASAN}

\section{Madrasah Pembangunan Ciputat: Membidik Kelas Sosial Menengah Kota}

Di tengah fenomena ketertinggalan madrasah dibandingkan sekolah umum,

\footnotetext{
Agama dan Keagamaan.

${ }^{9}$ Murtadlo dkk. 2011: dalam Studi Pembiayaan Pendidikan di Madrasah. Jakarta: Puslitbang Pendidikan Agama danKeagamaan
} 
Madrasah Pembangunan yang berlokasi di Ciputat Tangerang Selatan Banten dan berstatus sebagai madrasah swasta, berhasil keluar dari gambaran madrasah yang serba tertinggal dan membuktikan diri menjadi lembaga pendidikanyang berhasil. Madrasah Pembangunan berhasil menempatkan diri menjadi lembaga pendidikan yang diminati oleh masyarakat kelas ekonomi menengah di Kota Jakarta. Kenapa saya menyebut konsumen madrasah ini adalah masyarakat kelas sosial ekonomi menengah ke atas, hal ini saya simpulkan dari kemampuan orang tua membayar biaya pendidikan pada madrasah tersebut. Untuk tahun 2009, uang pangkal yang harus dibayarkan orang tua siswa kepada lembaga pendidikan itu sebanyak sepuluh juta rupiah. Jumlah yang cukup besar untuk ukuran biaya pendidikan jenjang sekolah dasar.

Untuk menggambarkan konsumen atau peminat dari Madrasah Pembangunan, berikut penulis paparkan data deskripsi latar belakang keluarga siswa MP. Berdasarkan data penerimaan siswa baru MP pada tahun 2010, menunjukkan bahwa semua ruang kelas I (Satu) sebanyak 8 ruang terisi penuh. Mengikuti prasyarat Sekolah Standar Nasional (SSN) yang mensyaratkan jumlah anggota tiap rombel yang ideal adalah 28 anak, maka MP hanya menampung delapan rombel dengan jumlah siswa baru sebanyak 224 anak. Kedelapan rombel/kelas dimaksud, dari tahun 2000 hingga tahun 2010 berhasil dipenuhi oleh MP, bahkan tidak jarang Madrasah Pembangunan menolak sebagian pendaftar yang lain.

Madrasah ini saya nilai telah berhasil dari sisi-sisi tertentu menjadi lembaga pendidikan yang diminati oleh masyarakat urban atau perkotaan di Jakarta.
Keberhasilan madrasah Pembangunan ini menarik perhatian masyarakat kelas menengah kota merupakan suatu fenomena baru, dan barangkali bisa dikatakan suatu model atau trend baru dalam sejarah pendidikan Islam di Indonesia. Sengaja dalam penelitian ini saya memilih obyek sebuah institusi pendidikan, yaitu fenomena madrasah Pembangunan sebagai jendela untuk memahami realitas madrasah secara lebih luas di Indonesia, karena alasan prestasi keberhasilan lembaga tersebut. Madrasah Pembangunan ini tidak saja melayani pendidikan formal tingkat dasar melalui Madrasah Ibtidaiyah (setingkat SD) dan Madrasah Tsanawiyah (setingkat SMP), tetapi juga melayani pendidikan tingkat menengah yaitu melalui Madrasah Aliyah (Setingkat SMA).

Gambar 1

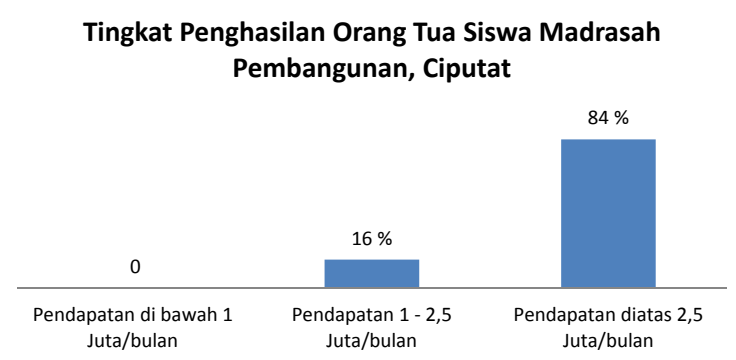

Sumber: Data Madrasah Pembangunan, Tahun 2010

Dilihat dari kelas ekonomi keluarga siswa Madrasah Pembangunan, diketahui bahwa sebagian besar (mayoritas) orang tua siswa MP berasal dari keluarga berkategori menengah. Hal ini dapat ditunjukkan dengan indikator kemampuan orang tua dalam memenuhi prasyarat untuk menjadi siswa MP yang harus membayar uang gedung sebesar Rp. 13 juta. Dari data di lembaga pendidikan tersebut (lihat tabel), diketahui bahwa orang tua yang berpendapatan 
kurang dari satu juta ternyata tidak ada, dari orang tua dengan pendapatan antara 1 juta s.d 2.5 juta terdapat $15.9 \%$; dari orang tua berpendapatan di atas 2.5 juta sebanyak 84.1 $\%$.Diduga, dibalik datatersebut masih banyak orang tua yang berpendapatan di atas 5 juta atau bahkan 10 juta, mengingat dari fasilitas antar jemput anak yang disediakan orang tua banyak menggunakan mobil pribadi dengan tahun keluaran di atas tahun 2000. Dari pendataan ini tidak terpetakan variasi diantara orang tua yang berpendapatan di atas 2.5 juta, karena budaya masyarakat kita belum terbiasa menyebutkan pendapatan riil mereka setiap bulan.

Gambar 2

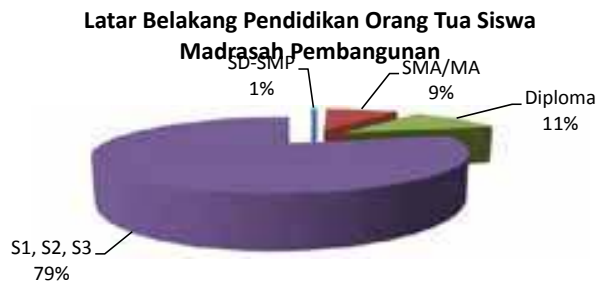

Sumber: Data Madrasah Pembangunan, Tahun 2010

Dilihat dari latar belakang pendidikan orang tua siswa dapat disebutkan mayoritas orang tua siswa MP berpendidikan sarjana baik itu Strata satu (S1), Strata Dua (S2) maupun Strata Tiga (S3). Data menunjukkan orang tua berpendidikan S1 ke atas sebanyak $78.7 \%$; orang tua berlatar belakang pendidikan Diploma sebanyak 11.5 \%; sedangkan orang tua berpendidikan SLTA ke bawah sebanyak $9.8 \%$. Ini menunjukkan bahwa orang tua peminat terhadap MP yang sebagaian besar berpendidikan S1 ke atas menunjukkan bahwa pilihan tersebut telah didukung oleh tingkat rasionalitas dan pendidikan yang memadai.
Gambar 3

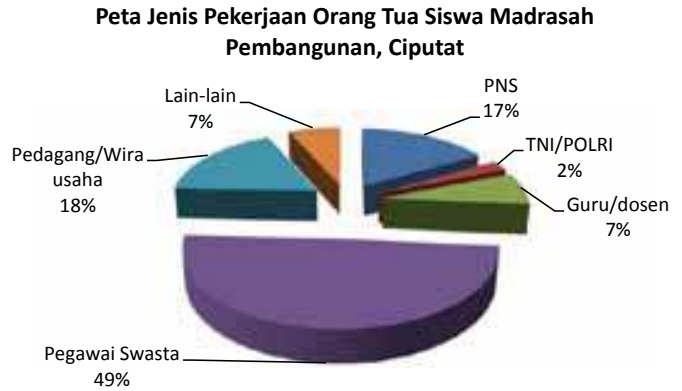

Sumber: Data Madrasah Pembangunan, Tahun 2010

Pekerjaan Orang Tua. Dari jenis pekerjaan yang menjadi profesi orang tua, dapat ditunjukkan bahwa sebagian besar adalah pegawai swasta (49 \%). Data ini menunjukkan bahwa madrasah ini berhasil menggaet minat orang tua dari kalangan swasta yang bisa memenuhi kebutuhan biaya pendidikan yang disyaratkan oleh madrasah ini. Selengkapnya dapat disebutkan orang tua berprofesi sebagai pegawai swasta sebanyak $49.3 \%$; pegawai negara (PNS dan TNI-POLRI) sebanyak $17 \%$; Guru/dosen sebanyak $7.5 \%$; pedagang/wirausaha sebanyak $18 \%$ dan lain-lain sebanyak $6.7 \%$ (lihat gambar).

\section{Strategi Pembiayaan Madrasah Pembangunan Ciputat}

Ketika sebagian besar madrasah, untuk kejelasan sumber pembiayaan pendidikan, berlomba mengusulkan diri menjadi madrasah negeri, Madrasah Pembangunan yang berlokasikan di Ciputat Tangerang Selatan ini justru mengambil langkah sebaliknya.MadrasahPembangunanmemilih untuk tetap menjadi madrasah dengan status swasta, tidak mau dinegerikan. ${ }^{10}$ Untuk

10 Pada tahun 1978, sesuai dengan Keputusan Dirjen Bimas Islam Depag RI, Nomor: Kep/D/03/1978, 
alasan kemandirian, status kelembagaan yang swasta dianggap lebih strategis dan menantang bila dibandingkan kalau lembaga ini menjadi negeri. Karena dengan begitu, para pengelola bisa memasang target sekaligus berimprovisasi dalam pencapaian target tertentu.

Menghadapi kebijakan pemerintah terkait pendidikan gratis dan implementasi pembiayaan oleh pemerintah daerah yang bernuansa diskriminatif ini, Madrasah Pembangunan yang berdiri pada tahun 1972 tidak patah semangat. Justru keadaan itu dijadikan cambuk untuk membuktikan bahwa madrasah tetap bisa survive ditengah keadaan yang menghimpit. Kenyataannya, Madrasah Pembangunan tidak saja berhasil mengatasi persoalan pembiayaan pendidikan, namun juga berhasil membuktikan diri menjadi madrasah unggulan, bahkan di ibukota RI, Jakarta.

Menurut para pengelola madrasah ini mengelola lembaga pendidikan dan menjadikan sekolah unggulan sebenarnya bisa dilakukan oleh masyarakat sendiri tanpa tergantung kepada negara. Walau tidak dipungkiri madrasah Pembangunan menerima juga dana BOS dan bantuan dana pendidikan yang diberikan kementerian agama. Madrasah perlu mengerahkan segenap kemampuan untuk menjadi lembaga pendidikan yang mandiri dan berani bersikap dalam kondisi apapun. Di tengah kebijakan pemerintah yang menggratiskan biaya sekolah kepada siswa, Madrasah Pembangunan justru menarik biaya dari siswa dan bahkan menrik SPP lebih

Madrasah Pembangunan karena keberhasilannya dinyatakan sebagai Madrasah Pilot Proyek Percontohan. tinggi dibandingkan madrasah sederajat di sekitarnya. Akibat dari kebijakan ini, ternyata madrasah justru semakin diminati masyarakat dan penerimaan siswa setiap tahunnya selalu penuh.

Strategi dengan menaikkan iuran murid ini pernah menjadi catatan kritik, seolah Madrasah Pembangunan hanya membidik golongan social ekonomi menengah ke atas. Namun kritik itu dibantah oleh salah seorang guru, dengan mengatakan:

Madrasah Pembangunan sebenarnya tidak membidik calon siswa dari masyarakat ekonomi kelas menengah ke atas, hanya saja ketika ditawarkan prasyarat untuk mengikuti proses pendidikan dengan jumlah biaya tertentu, ternyata masyarakat mampu memenuhinya, dan semua kelas terpenuhi ... ${ }^{11}$

Menaikkan biaya pendidikan pada satuan lembaga pendidikan biasanya mempunyai konsekwensi tertentu bagi satuan pendidikan tersebut. Hal itu disadari betul oleh Madrasah Pembangunan. Menyadari implikasi tersebut, Madrasah Pembangunan memilih menjadi lembaga pendidikan swasta. Dengan menjadi lembaga pendidikan swasta, maka Madrasah Pembangunan bisa menentukan harga biaya pendidikan yang ditawarkan. Kutipan berikut ini nampak sekali mengisyaratkan bahwa untuk mewujudkan pendidikan bermutu maka lembaga pendidikan ini sejak awal menerapkan biaya yang lebih tinggi. Strategi biaya lebih tinggi untuk meningkatkan mutu pendidikan ini adalah strategi yang biasa diambil oleh lembaga pendidikan swasta.

${ }^{11}$ Wawancara dengan YS, Wakil Kepala Madrasah Pembangunan, tanggal 25 Januari 2008 
Ibu M, seorang guru yang telah mengajar di MP selama 33 tahun, yaitu sejak tahun 1976 bercerita bahwa Madrasah Pembangunan sejak awal didirikan untuk menjadi sekolah yang bermutu. Didirikan oleh masyarakat komplek perumahan dosen UIN Syarif Hidayatullah yang kebanyakan adalah para dosen di perguruan tinggi tersebut. Sambutan terhadap kehadiran madrasah datang tidak hanya dari masyarakat yang tinggal di dalam kompleks. Dari luar komplek pun banyak masyarakat yang memasukkan anaknya ke madrasah. Madrasah Pembangunan sejak awal, mengingat statusnya yang swasta, menetapkan biaya yang sedikit lebih tinggi dibandingkan dengan beberapa sekolah di sekelilingnya. Keberatan tentang biaya justru datang dari masyarakat dalam kompleks. Namun setelah dijelaskan maksudnya, keberatan itupun sirna. Sementara masyarakat luar komplek yang menyekolahkan ke madrasah tersebut justru kebanyakan dari para pegawai atau pengusaha swasta. Kebanyakan pegawai negeri di luar kompleks menyekolahkan anaknya ke sekolah negeri baik sekolah dasar atau madrasah negeri.

Murid MP mulai melonjak banyak ketika MP sering tampil di Televisi. Melalui acara menyanyi atau cerdas cermat, Madrasah Pembangunan mulai dikenal oleh masyarakat luas. Sejak itu muridmurid mulai berdatangan. Biaya yang sedikit mahal tidak lagi menjadi soal bagi para orang tua yang ingin menyekolahkan anaknya ke Madrasah Pembangunan. ${ }^{12}$

Dari cerita di atas, ada beberapa poin bisa digarisbawahi terkait dengan kebijakan Madrasah Pembangunan mengembangkan lembaga pendidikan

${ }^{12}$ Wawancara dengan Ibu Mtq, guru senior di Madrasah Pembangunan. Wawancara dilakukan pada tanggal 7 Nopember 2007 yang mandiri dan mampu berkontestasi dalam konteks globalisasi. Pertama, bahwa madrasah ini sejak awal memang telah digagas untuk menjadi sekolah yang lebih bermutu. Keinginan ini terkait dengan keberadaan madrasah ini yang berada di lingkungan perumahan orang terdidik, yaitu di lingkungan perumahan para dosen UIN Syarif Hidayatullah Jakarta. Kedua, untuk meraih mutu yang diinginkan, madrasah ini menetapkan biaya yang lebih tinggi dibandingkan dengan biaya sekolah disekitarnya. Ini nampaknya terkait juga dengan kebijakan kenapa madrasah ini memilih berstatus swasta, tidak mau dijadikan madrasah negeri. Ketiga, perkembangan madrasah ini banyak didukung oleh peran masyarakat yang justru berasal dari kalangan pegawai swasta, di mulai masyarakat sekitar di luar komplek Perumahan hingga masyarakat secara lebih luas. Keempat, madrasah ini semakin meningkat jumlah peminatnya ketika madrasah ini mulai melakukan usaha promosi atau membangun image melalui pemunculan kegiatan siswa madrasah melalui layar televise.

... Madrasah Pembangunan sejak awal didirikan untuk menjadi sekolah yang bermutu. .... Madrasah Pembangunan sejak awal, mengingat statusnya yang swasta, menetapkan biaya yang sedikit lebih tinggi dibandingkan dengan beberapa sekolah di sekelilingnya. Keberatan tentang biaya justru datang dari masyarakat dalam kompleks. Namun setelah dijelaskan maksudnya, keberatan itupun sirna. .... ${ }^{13}$

${ }^{13}$ Penjelasan Ibu Mtq, Wawancara dilakukan pada tanggal 7 Nopember 2007 
Dariberbagaipertimbanganitu,akhirnya Madrasah Pembangunan dalam masalah pembiayaan pendidikan menerapkan strategi: 1) menetapkan sumbangan dalam jumlah tertentu bagi siswa yang diterima di madrasah tersebut. Pada saat ini jumlah bantuan sudah di atas 15 juta rupiah. Dana itu nantinya dialokasikan untuk dana investasi dalam pembangunan gedung dan pengadaan prasarana yang tahan lama; 2) mewajibkan siswa untuk membayar SPP bulan yang jumlahnya lebih tinggi dibanding madrasah di sekitar. Dana ini nantinya dipergunakan untuk dana operasional bulanan, dan secara lebih khusus untuk mengkover honor/gaji pendidik dan tenaga kependidikan; 3) menerima bantuan dana dari pemerintah dalam bentuk dana BOS; 4) setiap tahun ajaran baru siswa diwajibkan membayar Uang Tahun ajaran baru. Dana ini siperuntukkan untuk seragam, buku-buku dan kegiatan ekstrakurikuler; 5) dana paket bantuan (tentatif tergantung pihak sponsor yang memberikan bantuan program).

Kelima sumber pembiayaan itu dikelola sedemikian rupa untu jalannya proses belajar mengajar. Dana sumbangan awal dialokasikan untu dana investasi dalam bentuk pembangunan gedung dan peralatan yang berjangka panjang, sedangkan dana yang berasal dari SPP dan dana BOS dipergunakan untuk dana operasional bulanan. Dana tahun ajaran baru dipergunakan untuk barang-barang yang kembali ke siswa secara langsung. Khusus dana BOS didistribusikan sebagaimana pedoman yang diberikan Kemdikbud dalam mengelola dana BOS. Sementara itu dana paket bantuan dipergunakan sebagaimana peruntukannya yang diarahkan dari lembaga pemberi bantuan. Berikut peta penggunaan dana terkumpul dalam dilihat dalam matriks berikut:

\section{Matriks 1}

Jenis, Sumber Dan Alokasi Pembiayaan

Pada Madrasah Pembangunan (2016)

\begin{tabular}{|c|c|c|c|c|}
\hline $\begin{array}{l}\text { Jenis } \\
\text { Biaya }\end{array}$ & Asal & $\begin{array}{c}\text { Penggu- } \\
\text { naan } \\
\text { Biaya }\end{array}$ & $\begin{array}{l}\text { Prosen- } \\
\text { tase } \\
\text { cover } \\
\text { area }\end{array}$ & Peruntukan \\
\hline $\begin{array}{l}\text { Uang } \\
\text { Pangkal } \\
\text { Siswa } \\
\text { Baru }\end{array}$ & Orang Tua & $\begin{array}{l}\text { Biaya } \\
\text { Investasi }\end{array}$ & $100 \%$ & $\begin{array}{l}\text { Pembangunan } \\
\text { Gedung } \\
\text { Pemeliharaan } \\
\text { Gedung } \\
\text { Peralatan Permanen } \\
\text { Pemeliharaan } \\
\text { Peralatan Permanen }\end{array}$ \\
\hline $\begin{array}{l}\text { Dana } \\
\text { BOS }\end{array}$ & $\begin{array}{l}\text { Peme- } \\
\text { rintah }\end{array}$ & $\begin{array}{l}\text { Biaya } \\
\text { Opera- }\end{array}$ & & $\begin{array}{l}14 \text { item } \\
\text { penggunaan } \\
\text { dana BOS yang } \\
\text { direkomendasikan } \\
\text { Kemdikbud.) }\end{array}$ \\
\hline $\begin{array}{l}\text { SPP/ } \\
\text { Bulan }\end{array}$ & $\begin{array}{l}\text { Orang } \\
\text { Tua }\end{array}$ & sion & $85 \%$ & $\begin{array}{l}\text { Gaji/honor (70 \%) } \\
\text { Pengembangan SDM } \\
\text { Operasional lainnya }\end{array}$ \\
\hline $\begin{array}{l}\text { Uang } \\
\text { Tahun } \\
\text { Ajaran } \\
\text { Baru }\end{array}$ & Orang Tua & $\begin{array}{l}\text { Biaya } \\
\text { Tambahan }\end{array}$ & $100 \%$ & $\begin{array}{l}\text { Seragam } \\
\text { Buku-buku } \\
\text { Kegiatan Ekstra } \\
\text { Kurikuler }\end{array}$ \\
\hline $\begin{array}{l}\text { Dana } \\
\text { Paket } \\
\text { Bantuan }\end{array}$ & $\begin{array}{l}\text { Sponsor: } \\
\text { Peme- } \\
\text { rintah/ } \\
\text { Swasta }\end{array}$ & $\begin{array}{l}\text { Biaya } \\
\text { Program }\end{array}$ & $100 \%$ & $\begin{array}{l}\text { Sesuai dengan } \\
\text { Program Sponsor }\end{array}$ \\
\hline
\end{tabular}

Madrasah Pembangunan ciputat sendiri termasuk madrasah swasta yang menerima BOS sekaligus meminta SPP dari orang tua siswa. Bagaimana Madrasah Pembangunan mengatasi kekurangan pembiayaan pendidikan tersebut? Kepala Madrasah Pembanangunan, menyatakan bahwa dana BOS itu baru mencukupi dana operasional rutin sekitar $15 \%$ dari total 
kebutuhan rutin bulanan. Karena itu, Madrasah Pembangunan atas persetujuan Komite Madrasah setempat meminta SPP dari orang tua sebanyak $450.000 /$ bulan. ${ }^{14}$ Uang itu untuk memenuhi 85 \% kekurangan anggaran.

Menurut keterangan Kepala MI Pembangunan, dana yang terkumpul dari SPP dialokasikan sebagian besar untuk gaji/ honor guru dan tenaga kependidikan, yaitu sekitar $70 \%$. Sisanya $30 \%$ untuk mendukung kekurangan operasional rutin di luar gaji/ honor sebagaimana item-item pembiayaan BOS yang direkomendasikan Kemdikbud, khususnya pengembangan pendidik dan tenaga kependidikan.

\section{Permasalahan Pembiayaan Pendidikan di Madrasah}

Menghadapi kebijakan pendidikan gratis, setelah adanya kebijakan nasional pemberian Bantuan Operasional Siswa (BOS), madrasah swasta yang ingin mengejar keunggulan perlu punya strategi khusus untuk menjalankan proses belajar mengajarnya.Kebanyakan madrasah, karena dijiwai rasa ikhlasnya mengembangkan ilmu agama, banyak yang tidak mempunyai pilihan lain kecuali mengikuti himbauan pemerintah untuk tidak memungut lagi biaya pendidikan dari siswa/orang tua siswa. Pilihan ini bukan tanpa konsekwensi, karena pembiyaan dari dana BOS masih lebih banyak fokus kepada kebutuhan siswa, sedang tenaga pendidi dan kependidikan belum mendapatkan apresiasi yang layak dan memadai.

${ }^{14}$ Wawancara dengan Yon Sugiono, Kepala MI Pembangunan, 19 Jjuni 2016
Karena itu bagi madrasah sawsta yng ingin menggenjot kualitas pendidikan dan merebut minat masyarakat harus berani mengambil sikap tertentu. Ada beberapa pokokpikiransekitarpembiayaanpendidikan di madrasah yang harus difikirkan bagi madrasah yang ingin merancang bangun keberhasilan lembaganya. Berikut beberapa bahasan penulis terhadap pokok-pokok pikiran di sekitar masalah tersebut, sekaligus bagaimana Madrasah Pembangunan mensikapi persoalan tersebut.

\section{Menghitung Kontribusi Dana BOS pada Madrasah}

Program Bantuan Operasional Sekolah (BOS) yang dimulai sejak bulan Juli 2005, telah berperan besar dalam percepatan pencapaian program wajar 9 tahun tersebut. Oleh karena itu, mulai tahun 2009 pemerintah akan melakukan perubahan tujuan, pendekatan dan orientasi dari program. Peningkatan biaya satuan BOS tahun 2009yang cukup signifikan merupakan salah satu bukti komitmen pemerintah dalam menyelenggarakan amanat UUD perihal 20\% anggaran untuk pendidikan. Komitmen pemerintah ini harus juga diikuti oleh peningkatan komitmen pemerintah daerah serta peran serta masyarakat dalam pengawasan program dan pendanaan.

Sumber utama pembiayaan pendidikan dasar pada satuan pendidikan yang berstatus swasta di Indonesia saat ini banyak bergantung dengan dana Bantuan Operasional Sekolah (BOS) yang diperhitungkan berdasarkan jumlah siswa. Besaran dana Bantuan Operasional Siswa (BOS) saat ini terdiri dari: untuk siswa jenjang MI/SD sebesar Rp. 800.000,- per 
tahun. Pertanyaan utama yang menarik diajukan adalah seberapa besar dana BOS berkontribusi mencukupi kebutuhan pembiayaan di madrasah/sekolah? Apakah dana BOS telah mencukupi kebutuhan pembiayaan pendidikan satuan madrasah? Pertanyaan ini menarik dijawab, mengingat semua satuan pendidikan dasar saat ini mengandalkan dana BOS sebagai motor penggerak utama pembiayaan penyelenggaraan pendidikan.

Berdasarkan kajian Murtadlo (2011), ada fakta menarik bahwa pada madrasah swasta, apabila diajukan pertanyaan seberapa besar dana BOS telah membantu pembiayaan pendidikan (dilihat dari Rencana Anggaran Belanja (RAB) madrasah). Pada kmadrasahmadrasah swasta, dari kajian ini didapatkan hasil, bahwa kehadiran BOS secara ratarata telah membantu $68.18 \%$ dari total pembiayaan pendidikan. Bagi madrasah swasta yang selama ini mengandalkan SPP siswa, dengan adanya BOS, pembiayaan pendidikan mereka menjadi lebih lancar. Berbeda dengan ketika saat mengandalkan SPP yang tidak semua penarikan dari siswa berjalan lancar. Walaupun jumlah itu tetap saja kurang, karena misalnya honor guru belum dihargai dengan tunjangan yang layak (minimal setara dengan UMR). Hal ini berbeda ketika ditanyakan pada madrasahmadrasah negeri, mereka merasakan bahwa dana BOS rata-rata baru mampu menkover 29,15\% anggaran belanja madrasah negeri.

Respon madrasah terhadap adanya dana BOS ini kebanyakan adalah madrasah swasta merasa sangat terbantu dengan kehadiran dana BOS sebagai sumber pembiayaan pendidikan. Apalagi bagi madrasah yang mempunyai jumlah siswa yang banyak, karena secara otomatis, madrasah yang memiliki jumlah siswa lebih banyak akan menerima dana BOS lebih banyak. Hal itu terjadi, mengingat perhitungan pemberian bantuan dana BOS didasarkan pada jumlah kepala siswa. Dengan dana yang lebih banyak, maka madrasah swasta dapat memngangkat nilai gaji/honor bagi tenaga pendidik dan tenaga kependidikannya.

Menghadapi imbauan pendidikan gratis, di kalangan madrasah swasta muncul dua sikap: Pertama, madrasah swasta yang merasa terbantu dengan adanya dana BOS mengikuti himbauan pemerintah untuk menerima siswa tanpa dipungut biaya (gratis). Kebijakan ini tentu mengandung konsekwensi bahwa pendidik dan tenaga kependidikan, sekalipun dengan honor/gaji yang sedikit, mereka harus menjalankan proses belajar-mengajar (PBM); Kedua, madrasah swasta yang menerima dana BOS, namun tetap memungut SPP dari orang tua siswa. Alasannya dana BOS tidak cukup, sehingga kesulitan madrasah untuk bertahan, apalagi mengejar mutu pendidikan.

Madrasah Pembangunan Ciputat Tangerang Selatan ini mengakui bahwa dana BOS membantu kelancaran biaya pendidikan. Namun menurut pengelola dana BOS baru mengkover $15 \%$ dari total anggaran pendidikannya. Karena ini, Madrasah Pembangunan mengambil sikap menerima bantuan dana BOS, sekaligus mengambiluang partisipasidari siswa/orang tua siswa. Hal ini dipandang perlu, karena Madrasah Pembangunan berkepentingan untuk mewujudkan lembaga pendidikan berkeunggulan. Tanpa biaya tambahan dari orang tua siswa, rasanya mustahil mewujudkan layanan pendidikan yang bermutu. 


\section{Kebutuhan Pembiayaan Pendidikan di Madrasah}

Untuk mengetahui kebutuhan utuh pembiayaan pendidikan di Madrasah, kita perlu melihat secara komprehensip kebutuhan satuan pendidikan madrasah. Membaca komponen pembiayaan di madrasah, perlu dibedakan dengan melihat praktek di sekolah (umum), mengingat madrasah di Indonesia mayoritas adalah swasta. Kalau sekolah umum kabanyakan adalah sekolah negeri, dengan guru yang kebanyakan adalah pegawai Negeri Sipil (PNS) dengan jumlah gaji/honor yang standar; maka pada madrasah yang kebanyakan adalah swasta, dan gurunyapun kebanyakan adalah swasta/honorer berimplikasi pada model pembiayaan pendidikan yang berbeda diantara keduanya.

Sebagaimana telah disebutkan dalam kerangka konseptual, Peraturan Pemerintah Nomor 19 Tahun 2005 tentang Standar Nasional Pendidikan, yang merupakan peraturan pelaksanaan UU Sisdiknas No. 20/2003 menjelaskan bahwa pembiayaan pendidikan terdiri atas tiga jenis biaya, yaitu: (1) biaya investasi, (2) biaya operasional, dan (3) biaya personal. Demikian juga PP Nomor 48 Tahun 2008 tentang Pendanaan Pendidikan, menyatakan bahwa pendanaan pendidikan menjadi tanggung jawab bersama antara pemerintah, pemerintah daerah dan masyarakat.

Belajar dari kasus Madrasah Pembangunan, pengkaji di sini kemudian merasa perlu membuat beberapa skema pembiayaan pendidikan berdasarkan proses Belajar Mengajar (PBM). Skema diperlukan untuk menjadi dasar acuan sejauh mana kita menyelenggarakan layan pendidikan madrasah. Untuk memudahkan pembacaan, di sini pengkaji merumuskannya menjadi tiga model atau paket pembiayaan : a) Paket Dasar; b) paket menengah; dan c) paket Ekstra. Ketiga paket atau model itu bisa dijelaskan sebagai berikut :

Pertama, Paket Dasar yaitu merupakan paket pembiayaan minimal untuk berjalannya proses pembelajaran pada satuan pendidikan. Paket pembiayaan ini merupakan biaya operasional yang terdiri dari 2 komponen, yaitu komponen gaji dan honor pendidik dan tenaga kependidikan (operasional gaji/honor ), dan komponen peralatan habis pakai (operasional NonGaji/Honor ).

Kedua, Paket Menengah Paket Menengah merupakan paket tahap berikutnya dari pembiayaan pendidikan di madrasah, yaitu pembiayaan yang sudah mengkalkulasi dana investasi dalam pembiayaan pendidikan. Dana investasi merupakan penghitungan dana terhadap barang dan jasa yang nilai gunanya tidak sekali habis atau mempunyai rentang waktu yang lama. Biaya investasi dapat berupa pembiayaan untuk pengadaan sarana prasarana yang berjangka lama seperti ruang kelas baru (RKB); bisa juga yang terkait dengan pengembangan Sumber Daya Manusia (SDM) seperti guru menempuh pendidikan lanjut S2, S3 atau shortcourse tertentu; bisa juga biaya investasi ini berupa modal tetap seperti pengadaan tanah. Sumber pembiayaan paket ini dapat berasal dari blockgrand dari pemerintah pusat, bantuan dari pemerintah daerah, dan sumbangan orang tua (masyarakat).

Ketiga Paket Ekstra, Paket Ekstra merupakan bentuk pembiayaan yang telah mampu membuka program-program khusus yang dilakukan di satuan pendidikan 
tertentu untuk menunjukkan nilai beda dengan satuan pendidikan laiunnya. Program khusus itu bisa jadi merupakan paket ujicoba yang diinisiasi oleh pemerintah pusat (Kemenag), atau pemerintah daerah, atau oleh satuan pendidikan itu sendiri.
Paket biaya ini bisa berupa pemacuan peningkatan mutu, pengembangan kekhasan satuan pendidikan. Sumber pembiayaan dapat berasala dari pihak inisiator seperti Kemenag pusat, pemerintah daerah, atau orang tua siswa.

Matriks 2

Model/Paket Pembiayaan di Madrasah

\begin{tabular}{|c|c|c|c|c|}
\hline & Deskripsi & $\begin{array}{l}\text { Keterlibatan Jenis } \\
\text { Pembiayaan }\end{array}$ & $\begin{array}{l}\text { Konsentrasi Utama } \\
\text { Pembiayaan }\end{array}$ & Sumber Biaya*) \\
\hline \multirow[t]{2}{*}{ Paket Dasar } & \multirow{2}{*}{$\begin{array}{l}\text { Pembiayaan pendidikan } \\
\text { yang lebih fokus pada } \\
\text { terlaksananya PBM }\end{array}$} & \multirow[t]{2}{*}{ Biaya Operasional } & $\begin{array}{l}\text { Dana gaji/honor : gaji/ } \\
\text { honor guru }\end{array}$ & \multirow[t]{2}{*}{$\begin{array}{l}\sim \text { Dana BOS } \\
\sim \text { SPP }\end{array}$} \\
\hline & & & $\begin{array}{l}\text { Dana Non-Gaji/Honor } \\
\text { (biaya peralatan habis } \\
\text { pakai) }\end{array}$ & \\
\hline \multirow[t]{3}{*}{$\begin{array}{l}\text { Paket } \\
\text { Menengah }\end{array}$} & \multirow{3}{*}{$\begin{array}{l}\text { Pembiayaan Pendidikan yang } \\
\text { sudah memasukkan dana } \\
\text { investasi secara memadai }\end{array}$} & \multirow{3}{*}{$\begin{array}{l}\text { Biaya Operasional } \\
\sim \text { Biaya Investasi }\end{array}$} & $\begin{array}{l}\text { Dana gaji/honor : gaji/ } \\
\text { honor guru }\end{array}$ & \multirow{2}{*}{$\begin{array}{l}\sim \text { Dana BOS } \\
\sim \text { SPP }\end{array}$} \\
\hline & & & $\begin{array}{l}\text { Dana Non-Gaji/Honor } \\
\text { (biaya peralatan habis } \\
\text { pakai) }\end{array}$ & \\
\hline & & & Dana investasi & Uang Pangkal Pendidikan \\
\hline \multirow[t]{4}{*}{$\begin{array}{l}\text { Paket Ekstra } \\
\text { (Unggulan) }\end{array}$} & \multirow{4}{*}{$\begin{array}{l}\text { Pembiayaan Pendidikan yang } \\
\text { sudah memasukkan dana } \\
\text { investasi dan pengembangan } \\
\text { program-program khusus } \\
\text { tertentu }\end{array}$} & \multirow{4}{*}{$\begin{array}{l}\text { Biaya Operasional } \\
\sim \text { Biaya Investasi } \\
\sim \text { Biaya Program }\end{array}$} & $\begin{array}{l}\text { Dana gaji/honor : gaji/ } \\
\text { honor guru }\end{array}$ & \multirow{2}{*}{$\begin{array}{l}\sim \text { Dana BOS } \\
\sim \text { SPP }\end{array}$} \\
\hline & & & $\begin{array}{l}\text { Dana Non-Gaji/Honor } \\
\text { (biaya peralatan habis } \\
\text { pakai) }\end{array}$ & \\
\hline & & & Dana investasi & Uang pangkal \\
\hline & & & Dana Program khusus & $\begin{aligned} \sim & \text { Uang Tahun Ajaran Baru } \\
\sim & \text { Sponsor tertentu } \\
& \text { (Pemerintah, Orang Tua) }\end{aligned}$ \\
\hline
\end{tabular}

*) Praktek Pada Madrasah Pembangunan Ciputat

Dari skema di atas, maka kita tahu bahwa himbauan dengan adanya dana BOS, bahwa madrasah atau sekolah swasta harus membebaskan siswa dari biaya apapun (gratis) berdasarkan skema diatas hanya melihat penyelenggaraan pendidikan dalam model yang paling dasar. Maka bisa dibayangkan bahwa lembaga pendidikan yang hanya memenuhi aspek kebutuhan dasar saja, maka lembaga itu belum bisa dituntut kualitasnya.

\section{Komponen Operasional Rutin Madrasah}

Penelitian ini selanjutnya difokuskan kepada pemetaan kebutuhan pembiayaan dasar pembelajaran (operasional) rutin, mengingat komponen ini merupakan roda utama pendidikan nasional yang dijalankan saat ini. Biaya operasional, terdiri dari biaya gaji/honor dan biaya nongaji/honor. Biaya gaji/honor terdiri dari gaji pendidik dan tenaga kependidikan serta tunjangantunjangan yang melekat pada gaji. Biaya nongaji/honor adalah biaya untuk bahan 
atau peralatan pendidikan habis pakai, dan biaya tak langsung berupa daya, air, jasa telekomunikasi, pemeliharaan sarana dan prasarana, uang lembur, transportasi, konsumsi, pajak, asuransi, dll.

Untuk mengetahui konstruk biaya pendidikan di madrasah, kita perlu mengetahui komponen pembiayaan pendidikan di lembaga pendidikan tersebut. Penelitian Puslitbang Penda (2006) tentang "studi Unit cost satuan pendidikan di Madrasah Swasta" yang dilakukan Puslitbang pendidikan agama dan keagamaan kementerian Agama RI bekerja Sama dengan Peneliti Universitas Pendidikan Indonesia (UPI) Bandung pernah menyebutkan Komponen-komponen pembiayaan yang seharusnya dibiayai dalam penyelenggaraan satuan pendidikan pada jenjang pendidikan madrasah swasta tingkat MI dan MTs agar memiliki kualitas dan daya saing dengan jenis-jenis pendidikan persekolahan lainnya. Daftar kebutuhan tersebut terdiri dari tujuh komponen utama dan 57 rincian. Ketujuh komponen itu terdiri dari: 1) Komponen Kesejahteraan Personel; 2) Komponen Pengembangan Personel; 3) Komponen Penunjang KBM; 4) Komponen Pemeliharaan dan Penggantian; 5) Komponen Daya dan Jasa; 6) Komponen Pembinaan Kesiswaan; 7) Komponen Rumah Tangga Madrasah (Overhead).

Ketujuh komponen itu, secara ideal untuk mewujudkan pendidikan yang memadai perlu dipenuhi. Namun karena dunia madrasah umumnya mempunyai dana yang terbatas, maka penulis mencoba melacak kebutuhan pembiayaan dengan formula yang lebih minimal. Dari kajian peneliti (2011), pengkaji menemukan di antara madrasah ternyata masing-masing madrasah mempunyai kebijakan masingmasing. Perbedaan menyolok antara madrasah swasta dan madrasah negeri terjadi pada alokasi honor pendidik dan tenaga kependidikan. Kalau di madrasah swasta dari total dana bantuan pemerintah melalui BOS, terserap paling banyak pada belanja pegawai, berkebalikan dengan madrasah negeri yang tidak terbebani belanja pegawai. ${ }^{15}$

Untuk memperjelas rumusan komponen utama dan prosentase pembiayaan untuk masing-masing komponen yang dibutuhkan dalam pembiayaan pendidikan di madrasah secara minimal, penulis berkesempatan melakukan Forum Group Discussion (FGD), di Kanwil Makassar, yang dihadiri para perwakilan Mapenda Kabupaten dan provinsi. FGD ini memperolh simpulan bahwa ada 7 (tujuh) pokok pembiayaan pendidikan madrasah, yang wajib dialokasikan atau dibiayai. Ketujuh pokok itu adalah : 1) Honor guru; 2) Pengadaan buku pelajaran/perpustakaan; 3) Alat Tulis kelas; 4) Peralatan siswa; 5) Sumber Daya dan jasa; 6) Ujian; dan 7) Biaya rutin operasional

Dari item-item yang telah dianggap pokok itu, didapatkan jumlah prosentase alokasi yang merupakan kompromi yang dihasilkan dari FGD tersebut. Diskusi yang melibatkan kepala madrasah swasta dan negeri di lingkungan kota Makassar menghasilkan selain pokok-pokok yang wajib dibiayai sekaligus prosentase pembiayaan. Pada madrasah swasta kebutuhan pembiayaan yang paling besar adalah honor guru yaitu diusulkan 50).

${ }^{15}$ Hal ini wajar, mengingat pada madrasah negeri, gaji guru telah dicukupi dengan gaji pegawai yang rata-rata adalah Pegawai Negeri (PNS). 
Dari skala prosentase dapat diurutkan sebagai berikut: belanja pegawai (50 \%), pengadaan buku, langganan daya dan jasa, uang ujian, dana operasional (masingmasing $10 \%$ ), peralatan siswa dan peralatan kelas (masing-masing $5 \%$ ).

Matriks 3

Kebutuhan Anggaran Pembiayaan Pada Madrasah Swasta

\begin{tabular}{|c|l|c|}
\hline No & \multicolumn{1}{|c|}{ Pokok Pembiayaan } & $\begin{array}{c}\text { Madrasah Swasta } \\
\text { (\%) }\end{array}$ \\
\hline 1 & Honor Guru & 50 \\
\hline 2 & Buku Pelajaran/ perpustakaan & 10 \\
\hline 3 & Alat Tulis kelas & 5 \\
\hline 4 & Peralatan Siswa & 5 \\
\hline 5 & Sumber daya dan jasa & 10 \\
\hline 6 & Ujian & 10 \\
\hline 7 & Biaya rutin operasional & 10 \\
\hline & Total & 100 \\
\hline
\end{tabular}

Kalau dikembalikan dengan kebijakan pendidikan nasional saat ini, keberadaan dana BOS sejauh ini baru dapat membantu kelompok pembiayaan operasional. Itu artinya untuk kepentingan pembiayaan secara utuh, khususnya untuk madrasah swasta, masih membutuhkan sumber penganggaran lain. Apalagi dalam pembiayaan pendidikan dikenal beberapa kebutuhan pembiayaan khusus seperti pembiayaan investasi, pengembangan mutu, dan kemungkinan pengembangan kekhasan madrasah.

\section{Menghitung Gaji/Honor Guru Madrasah (Versi UMP)}

Sekalipun prosentase penyerapan untuk biaya gaji/honor di beberapa madrasah cukup besar, pertanyaannya: sudahkah cukup honor/gaji guru? Lebih ekstrimnya lagi, bila dianalogikan pendapatan minimal buru, sudahkan guru swasta pada madrasah swasta telah mampu mencapai Upah Minimum Provinsi (UMP). Dasar UMP menjadi penting, mengingat UMP adalah standar hidup minimal yang telah dijadikan ukuran bagi pemerintah daerah. Untuk mengukur biaya gaji/honor yang sepantasnya diterima guru di daerah adalah dengan melihat Upah Minimum Provinsi (UMP).

Ketika saya ajukan pemikiran bahwa gaji/honor Guru minimal adalah sama dengan UMP kepada teman-teman yang bergerak di dunia pendidikan terdapat dua respon. Pertama, menyamakan standar guru madrasah dengan UMP adalah tidak manusiawi, mengingat UMP sebenarnya disediakan hanya untuk tenaga kerja kasar, buruh dan kebanyakan lulusan SMA dan tidak mempunyai skills sebagaimana guru. Guru sebaiknya di atas UMP. Kedua, ada yang tertarik juga untuk minimal mempersamakan gaji guru paling tidak sama dengan UMP. Kalau yang terjadi di banyak satuan pendidikan di bawah UMP, itu lebih tidak manusiawi lagi.

Berangkat dari pertanyaan di atas, kita jadi tahu bahwa praktek pemberian honor/gaji khususnya pada pendidik dan tenaga kependidikan honorer di madrasah swasta dapat dikelompokkan ke dalam tiga kelompok;

Gaji/honor di bawah UMP; Gaji/honor guru masih berada di bawah Upah Minimum Provinsi. Data penelitian dari kasus-kasus yang diteliti menunjukkan dari 8 madrasah yang diteliti (lihat tabel), dengan tingkat akreditasi yang berbeda, menunjukkan hanya dua madrasah yang gaji/honor guru sudah berada di atas UMP (lihat tabel). 
Gaji/honor setara UMP; Gaji/honor guru madrasah sama atau di atas sedikit dari UMP. Melacak bahwa UMP belum dijadikan wacana umum untuk menggaji guru madrasah, yang terjadi dalam praktek ternyata jarak antara di bawah UMP dan di atas UMP secara ekstrim.

Gaji/honor di atas UMP; Gaji/honor guru madrasah di atas UMP. Ada beberapa madrasah yang sudah berhasil memberikan honor pegawai jauh di atas UMP. Biasanya hal yang demikian terjadi pada madrasah yang cukup mandiri atau madrasah yang banyak diminati masyarakat.

Membandingkan gaji/honor guru madrasah dengan Upah Minimum provinsi (UMP) sudah waktunya kita lakukan, mengingat banyak praktek satuan pendidikan dan pemerintah daerah yang belum bisa memberikan kesejahteraan guru di atas UMP yang diterima buruh atau pekerja pabrik. Bukankag guru adalah agen utama perubahan yang menghasilkan calon pemimpin bangsa, calon pengusaha, dan tentunya calon-calon buruh atau pekerja industri. Kelalaian kita meningkatkan kesejahteraan guru minimal sama atau justru di atas UMP menjadi keprihatinan besar kita. Hal itu menunjukkan bahwa kita belum menghargai profesi guru, atau masyarakat kita belum menghargai guru, pemerintah daerah kita juga belum memperhatikan nasib guru dan lebih jauh lagi negara belum bisa mensejahterakan guru.

Berangkat dari fakta seperti itu, pada tahun 2011 penulis pernah menelusuri UMP di berbagai daerah yang penulis jadikan sampel untuk membandingkan gaji/honor guru dengan UMP per daerah. Menurut Data Kementerian Tenaga Kerja dan Transmigrasi tahun 2011 dinyatakan bahwa besar upah minimum provinsi pada keenam sasaran yang kami teliti, yaitu di Sumatera selatan, jawa Barat, banten, Jawa tengah, Kalimantan Selatan dan Sulawesi selatan dapat dilihat dalam tabel berikut:

Matriks 4

Daftar Upah Minimum Provinsi (UMP)

Daerah Sasaran Penelitian, Tahun $2011^{16}$

\begin{tabular}{|l|cc|}
\hline \multicolumn{1}{|c|}{ Provinsi } & \multicolumn{2}{c|}{ Besar UMP } \\
\hline Sumatera Selatan & Rp. & $1.048 .000,-$ \\
\hline Jawa Barat & Rp. & $732.000,-$ \\
\hline Banten & Rp. & $1000.000,-$ \\
\hline Jawa Tengah & Rp. & $675.000,-$ \\
\hline Kalimantan Selatan & Rp. & $1.126 .000,-$ \\
\hline Sulawesi Selatan & Rp. & $1.100 .000,-$ \\
\hline
\end{tabular}

Idealnya, gaji/honor pendidik dan tenaga kependidikan madrasah swasta sudah memenuhi standar Upah Minimum Provinsi (UMP) masing-masing daerah. Apabila honor guru telah sama atau melebihi UMP maka, sewajarnyalah apabila masyarakat berhak mendapatkan layanan pendidikan yang memadai. Namun, seperti itukan penerimaan guru madrasah swasta di tanah air?

Berdasarkan perhitungan dari 8 kasus madrasah ibtidaiyah swasta, di daerahdaerah yang kita jadikan sampel, ternyata gaji/honor versi UMP baru bisa dicapai pada sebagian madrasah yang terakreditasi A, sebagaian dengan akreditasi yang sama belum bisa memenuhi UMP. Apalagi madrasah dengan akreditasi di bawahnya.

16 http://berita.manadotoday.com/ Daftar Upah Minimum Provinsi 2011 Seluruh Provinsi di Indonesia. (ditelusuri tgl 11 September 2011). 
Matriks 5

Keterpenuhan Gaji/Honor Guru terhadap Upah Minimum Provinsi (UMP)

Pada 8 Madrasah Swasta (2011)

\begin{tabular}{|l|c|c|c|c|c|}
\hline \multicolumn{1}{|c|}{ NAMA MADRASAH } & AKR & $\begin{array}{c}\text { RATA2 HONOR/ BLN } \\
\text { GURU }\end{array}$ & BESAR UMP & $\begin{array}{c}\% \\
\text { UMP }\end{array}$ & $\begin{array}{c}\text { STATUS PEMENUHAN } \\
\text { UMP }\end{array}$ \\
\hline MI Roudhotul Ulum Salatiga & A & 1.382 .353 & 675.000 & 204 & Sudah \\
\hline MI Al Khoiriyah 01 Semarang & A & 1.601 .157 & 675.000 & 237 & Sudah \\
\hline MI Nashrul Fajar Semarang & A & 620.583 & 675.000 & 91 & Belum \\
\hline MI Muslimin Sindangkerto Jabar & B & 487.014 & 732.000 & 66 & Belum \\
\hline MI Al Abrar Makassar & B & 122.588 & 1.100 .000 & 11 & Belum \\
\hline MI Roudhotudin Magelang & C & 178.571 & 675.000 & 26 & Belum \\
\hline MI Fajar Siddiq Sum Sel & C & 530.583 & 1.048 .000 & 50 & Belum \\
\hline MI Masdarul Ulum Ogan llir & TT & 187.500 & 1.048 .000 & 17 & Belum \\
\hline Rata-rata & & & & 88,3 & Belum \\
\hline
\end{tabular}

Dari daftar tabel di atas, secara keseluruhan sampel tingkat pemenuhan Upah Minimum Provinsi (UMP) oleh madrasah swasta pada berbagai provinsi menunjukkan masih berada pada angka $88,3 \%$. Itu artinya secara umum, UMP pada beberapa madrasah swasta (sampel) belum terpenuhi. Kemampuan membayar memenuhi UMP hanya terjadi pada madrasah yang berakreditasi A, itupun tidak semua.

Madrasah Pembangunan dengan model pembiayaan yang diterapkan sejauh ini, menurut pengakuan Kepala MI Pembangunan telah mampu menggaji Guru dan Tenaga Kependidikan di atas UMP Provinsi DKI Jakarta. Sekalipun Madrasah Pembangunan berlokasi di tangerang Selatan Banten, namun dari standar hidup bagi guru dan Ketenaga kependidikan disesuaikan dengan kelayakan hidup di ibukota RI.

Keberadaan Madrasah Pembangunan juga diakui semakin eksis di ibukota RI dengan berdiirinya gedung-gedung megah, tempat pembelajaran madrasah ini.
Madrasah ini malahan menjadi icon lembaga pendidikan yang berhasil di daerah Ciputat. Muncul kesan di sana sudah hadir sebuah sekolah dengan sarana-prasarana yang lengkap yang layak menggaet siswa-siswa dari masyarakat menengah kota. Berbeda dengan kebanyakan madrasah di tanah air yang memiliki masyarakat pendukung yang biasanya dari kelas masyarakat bawah, Madrasah Pembangunan berhasil membuktikan diri bahwa madrasah juga bisa menjadi sekolah dengan fasilitas yang memadai yang layak diminati oleh masyarakat kelas menengah kota.

\section{PENUTUP}

Dari paparan tentang strategi Pembiayaan pendidikan di madrasah, dapat digarisbawahi beberapa kesimpulan berikut : Pertama, terhadap kebijakan pemerintah yang menghimbau pendidikan gratis, sebagai konsekwensi penerimaan dana BOS, maka dunia madrasah terbelah menjadi dua: a) sebagian besar madrasah menerima dana BOS dan menggratiskan anak didik dari biaya pendidikan. Walaupun konsekwensi 
dari sikap ini madrasah masih mengabaikan kehidupan layak dari pendidik dan tenaga kependidikannya; dan b) Menerima dana BOS, namun tidak menggratiskan siswa dari biaya tambahan, dengan pertimbangan bahwa madrasah tidak cukup dengan dana yang tersedia dari dana BOS.

Kedua, Madrasah pembangunan Ciputat Tangerang Selatan sebagai kasus studi ini termasuk kelompok madrasah jenis kedua, yaitu menerima dana BOS dan menarik biaya pendidikan dari siswa/orang tua siswa. Bahkan dari jenis biaya tambahannya di madrasah ini terdapat beberapa dana tambahan, yaitu Uang pangkal siswa baru, uang SPP, Uang tahun ajaran baru. Dengan beberapa dana tambahan ini, bukannya lembaga madrasah ini dijauhi para konsumen. Justru sebaliknya madrasah ini tetap diminati masyarakat, khususnya dari segmen kelas menengah kota.

Ketiga, strategi pembiayaan pendidikan di madrasah hendaknya mengacu pada jaminan apa yang bisa diberikan satuan pendidikan kepada konsumen. Kalau konsumen merasa mendapatkan kepastian jaminan dengan program-programnya,maka sudah dapat dipastikan konsumen sanggup menanggung biaya yang dibutuhkan. Di sini letak strategis Komite Madrasah diperankan untuk membaca kemauan publik terhadap layanan pendidikan madrasah.

Penelitian ini merekomendasikan: pertama, perlunya satuan pendidikan madrasah swasta mengidentifikasikan jaminan mutu lembaganya dalam memberikan layanan pendidikan kepada masyarakat; kedua, birokrasi pendidikan di lingkungan kementerian agama perlu memetakan madrasah-madrasah dengan tipe dasar, menengah atau ekstra (unggul). Peta ini diperlukan untuk kepentingan ppembinaan. Ketiga, perlu dipikirkan gaji/ honor pendidik dan tenaga kependdidikan dengan kriteria dan syarat tertentu untuk mendapatkan hidup yang layak dari pengabdiannya sebagai guru atau tenaga pendidik di lingkungan madrasah swasta.

\section{UCAPAN TERIMAKASIH}

Tulisan ini rampung berkat dukungan semua pihak, karena itu penulis menyampaikan terimakasih kepada Kepala Puslitbang Pendidikan Agama dan Keagamaan Badan Litbang dan Diklat Kementerian Agama atas arahan dan bimbingannya, sejumlah narasumber informan yang bersedia memberikan data dan informasi, demikian juga kepada Mitra Bestari yang telah bersedia mengoreksi tulisan ini semoga tulisan ini memberikan wawasan dalam pendidikan agama di Indonesia.

\section{DAFTAR PUSTAKA}

Supriadi, Dedi (2003): Satuan Biaya Pendidikan: Dasar dan Menegah, Bandung, PT Remaja Rosdakarya

Mastuhu. (2006): Pendidikan Agama Islam Indonesia Sebagai Subsistem Pendidikan Nasional. Jurnal Edukasia, Puslitbang Pendidikan Agama dan Keagamaaan Dep. Agama RI, edisi 1.

Mulyana, Rochmat dkk. (2005): Unit cost Mahasiswa IAIN/STAIN, Jakarta: Puslitbang Pendidikan Agama dan Keagamaan. 
Penelitian Puslitbang Penda. (2006): Studi Unit Cost Satuan Pendidikan di Madrasah Swasta. Jakarta: Puslitbang Pendidikan Agama dan Keagamaan.

Muin, Abdul dkk. (2007): Biaya Satuan Madrasah Diniyah Awaliyah (2007). Jakarta: Puslitbang Pendidikan Agama dan Keagamaan.

Murtadlo dkk. (2011): dalam Studi Pembiayaan Pendidikan di Madrasah. Jakarta: Puslitbang Pendidikan Agama dan Keagamaan.

Pendidikan Agama Islam dalam Kemunduran, (Suara Merdeka, 10 Januari 2005)

Paparan Dirjend. Pendis pada dengar Pendapat Komisi VIII DPR RI, Januari.
Buku Penuntasan Wajar Dikdas Sembilan Tahun 2004-2009, DirektoratPendidikan Madrasah)

Daftar Upah Minimum Provinsi 2011 Seluruh Provinsi di Indonesia. http://berita. manadotoday.com/ (ditelusuri tgl 11 September 2011).

Wawancara dengan YS, Wakil Kepala Madrasah Pembangunan, tanggal 25 Januari 2008.

Wawancara dengan Ibu Mtq, guru senior di Madrasah Pembangunan. Wawancara dilakukan pada tanggal 7 Nopember 2007.

Wawancara dengan Yon Sugiono, Kepala MI Pembangunan, 19 Juni 2016. 